\title{
DRIVERS OF THE BOND MARKET PREMIUM IN OPEN AND SMALL ECONOMIES AROUND THE EUROZONE
}

\author{
[Faktory ovlivňující rizikovou prémii dluhopisů v malých a otevřených \\ ekonomikách mimo Eurozónu]
}

\author{
Mercédesz Mészáros ${ }^{1}$, Gábor Dávid Kiss ${ }^{2}$ \\ ${ }^{1}$ University of Szeged, Faculty of Economics and Business Administration, 6722 Szeged, Kálvária sgt. 1., \\ Hungary,Email:m.mercedesz@eco.u-szeged.hu \\ ${ }^{2}$ University of Szeged, Faculty of Economics and Business Administration, 6722 Szeged, Kálvária sgt. 1., \\ Hungary, Email: kiss.gabor.david@eco.u-szeged.hu
}

\begin{abstract}
Nowadays, the examination of bond markets is becoming more prominent as there have been significant changes in the financial market and economic policy processes due to the diverse economic shocks. The room for manoeuvre available for monetary policy is no longer a function of base rates, but rather of the growth of central bank balance sheets - which can also have side-effects on bond yield progresses. Also, QE is only the privilege of large central banks, if smaller central banks use these programs the yield premium will be elevated. Six European small open economies (Czechia, Denmark, Hungary, Poland, Switzerland, Sweden) outside the Eurozone were investigated on quarterly basis between 2007 and 2020 with Autoregressive Distributed Lag (ARDL) cointegration technique. The aim of our research was to identify the effects of the recent economic shocks - the economic crisis of 2008, the subsequent European sovereign debt crisis and the current corona virus epidemic - on the evolution of international bond yield premia time series in the light of monetary policy, macro variables and financial markets. The results were typically in line with expectations, except that no significant bond market impact of portfolio capital flow could be measured on the sample. The main outcome proved that the unconventional monetary policy increased yield premiums in these analysed countries, meaning that $\mathrm{QE}$ is not for small and open economies.
\end{abstract}

Keywords: ARDL, bond markets, QE, subprime crisis, unconventional monetary policy.

JEL classification: C33, E43, E44, E58, G15

Received: 1.10.2020; Reviewed: 3.11.2020; 14.12.2020; Accepted: 27.1.2021

\section{Introduction}

During the recent decade, especially after the economic crisis of 2008, advanced economies have become increasingly asset-focused, which is reflected not only in the central bank's asset purchases for strengthening the economy, but also in the fact that the shares of financial assets of households in GDP are showing an increasing trend. As a result, from the point of view of both the circumstances of the population and the situation of the national economy, it is important to analyse the changes in the asset prices and the mechanisms behind them. Nowadays, it is important to study credit markets, as it is an accepted correlation that moments that can be identified in the bond market can also affect the stock market, and that some other unique observations about bond markets can also forecast economic crises. Such as the shape of the yield curve, or when, in the event of market expectations related to a recession, capital flows towards safer government bonds, the yields of which fall and their exchange rates rise as a result. The conclusions that can be drawn from these observations may be distorted by the fact that bonds have become an instrument of monetary policy implementation through central bank quantitative easing programs.

These resulted in a decline in bond yields and an appreciation of bonds, as did a decline in central bank key interest rates to near-zero values. However, there were exceptions: in the bond 
market of some smaller countries, as in the case of Hungary, the opposite effect was observed; bond yields have risen, their exchange rates have fallen, as investors have not seen these government bonds as safe havens and have withdrawn capital from them - making the situation even worse. Today, monetary policy has seemingly reached its limits, leaving many new tools to boost the economy and tackle inflation. In addition, the coronavirus epidemic hit the world economy as a strong shock in 2019 , which according to some forecasts could lead to even the greatest peacetime recession of the century - and the drop in the world economy after this could be significantly different from that experienced after 2008.

The choice of our research topic was motivated by the observation that Europe is at the end of a business cycle, while most central banks continue to follow loose monetary policy. Despite the increase in leverage, the slowdown in the global economy, inflationary challenges and expected and unpredictable developments in the corona virus could cause further shocks in the markets. Before that, it is worthwhile to assess the consequences experienced so far, and to compare the current and previous situation. Even more so as examining the bond market effects is a less researched area in the literature - as we introduce in the theoretical background subsection - although the importance of the bond market has increased since the crisis. In addition, we also find countries and groups of countries (European economies outside the Eurozone) whose capital markets have not yet been researched from this perspective or only analysed by a very few studies (i.e.: Ciarlone and Colabella 2018). The analysis of the halocountries around the Eurozone gives us a refined cost-benefit evaluation of keeping the national currency and the relative monetary autonomy under these times when unconventional monetary policy became tempting for open and small economies as well.

For this reason, the aim of our research was to identify and compare the effects of major economic shocks after 2007, especially the economic crisis of 2008, the subsequent European sovereign debt crisis and the current corona virus epidemic, on the evolution of international bond yield premia time series. Our goal was to explore the specific aspects of the relationship between these shock events and credit market mechanisms, and within this, the situation of European small, open economies. The main research question of this study was that; which of the analysed (financial, macroeconomic, monetary policy and shock related) variables had the greatest impact on the bond yield premiums? Our sample covered small, open economies outside the Eurozone, whose financial markets experienced significant economic turbulences in the period between 2007 and 2020 - where, for example, an increase in asset price volatility appeared in several cases. Thus, the analysed sample consists of the Czech, Danish, Polish, Hungarian, Swiss and Swedish central banks, for which the entire sample was examined. The investigation of bond market is also interesting because a less analysed research area and a sufficiently liquid and developed bond market in terms of lessons learned from the past can also contribute to the effectiveness of the central bank's crisis management measures.

We answered our research question through econometric methods, precisely using Autoregressive Distributed Lag (ARDL) panel regressions, by which we tested the fulfilment of our pre-compiled empirical models. In most cases, our results were in line with the anticipated outcomes, but we also found discrepancies that led to the most important conclusion of our study - quantitative easing policy is not appropriate for small and open economies.

The study structured as follows: the first section summarizes the theoretical background of the impact of economic shocks on bond markets as well and contains the methods how we can measure them. This section also contains our theoretical models. The second section presents the examined dataset and the summary of ARDL panel models. Finally, the third section shows 
the results of the model testing and the last summarizes the main purpose and conclusions of our study.

\section{Theoretical background}

This section summarizes the main theoretical approaches about the European bond markets processes and the main side effects on them caused by the big financial crisis of 2008 and the sovereign debt crisis effects. It is also introducing the methods how to measure the impacts of these shocks and main changes they caused focusing on the monetary policy regime change, which we quantified in our examinations. The last subchapter contains our theoretical models.

Bond prices reflect not only expectations but also risks, and therefore, in addition to a risk-free return, they must also include some premium for investors to be willing to invest. There are different theories that explain differently what the direction of the premium is, what the determining factor of the premium is, and how constant the relationship is between the explanatory variables and the premium. The theory of liquidity preference is based on the fact that, due to the uncertain future, investors tend to tie up their capital for a shorter period of time, so longer-term bonds only at higher yields, a liquidity premium. However, according to preferred habitat theory, the risk premium may also decrease with increasing maturity, as longer-term securities pose a lower risk to investors with long liabilities, so these investors expect a liquidity premium for shorter-term assets. However, other effects can be captured in addition to these. In practice, the above factors usually influence the evolution of the yield curve at the same time, so a theory alone can rarely give an accurate explanation of the current shape of the yield curve (Veres 2016). For example, the short end of the yield curve is primarily driven by changes in short-term interest rates, i.e. monetary policy expectations, where different risk premia are less prevalent than, say, the long end of the yield curve, where market movements dominated by demand and supply conditions (Veres 2016).

Moreover, against the mainstream macroeconomic theory, the changes in the long-term interest rate are not solely derives from the changes in the expected path of future short-term interest rates but also by changes in the term premia. The chance of affecting the term premium in a direct way is one of the motivations behind the asset and security purchase programs of central banks. As Mallick et al. (2017) defined earlier that with growing uncertainty and risk aversion, investors generally demand more payment after holding risky assets such as long-term government securities. In addition, investors who constantly manage their portfolios may face stricter funding or capital constraints and are therefore forced to reduce their exposure. Thus, the marketability and liquidity of the bond market may decline, leading to wider fluctuations in bond yields (such as He and Krishnamurthy, 2013; Adrian and Shin, 2010). In contrast, a reduction in expected volatility may lead investors to take more risk which could diminish the term premia. If monetary policy influences investors' attitude about uncertainty and risk, thus bond market risk-taking may be an extra channel of monetary transmission. The connection between bond yield premia and monetary policy has not earned enough attention in the prior literature, even though the bond market has become increasingly important since the crisis.

\subsection{The financial crisis on bond markets}

In many cases the financial crisis showed that capital and financial markets do not operate according to rationality or just to the contexts experienced so far. But to start with a little precrisis period literature, and focusing on the bond markets, some researcher proved traditional correlations, like Pagano and Von Thadden (2004), where they demonstrated in the sample of Eurozone countries that credit risk alone determine a large piece of 10-year average yield differentials - as a result of as a result of the monetary union membership. In contrast Balli (2009) analysed the spillover effects on bond yields on the same sample Eurozone economies 
in the period from 1999 to 2005 and he showed that the variable of credit risk and other macro and fiscal variables are not enough to define sovereign bond yields after the transition to EMU. In the interval from 1998 to 2008, Afonso (2010) tested the connection between economic forecasts and long-term bonds in the case of Euro area countries and his results showed that the more positive growth forecasts and budget reductions the larger growth in yields. Claeys and Vašíček (2014) examined the connection between 16 EU sovereign bond markets through factor-augmented VAR (FAVAR) models and multivariate structural break tests and they proved significant spillover effects, mainly between the EMU countries. Their results also showed that the essential part of the turbulences in market movements are driven by massive shocks rather than by market contagion. Moreover, they proved that spillovers among sovereign yields increase considerably since 2007, but their importance is heterogeneous across countries. The authors find that spillover effects dominate the domestic fundamental factors for EMU countries.

The global financial crisis rapidly spread across borders and financial markets, and distressed EU bond markets. However, the subprime crisis did not hit all financial markets in the same way whose explanation remains an important research topic. Von Hagen et al. (2011) examined whether the USD and DM/Euro-denominated government bond spreads related to US and German benchmark bonds in the period before and after the beginning of the subprime crisis. Their result presented that bond yield spreads mostly defined based on the same explanatory variables during both eras. Their another finding is that markets punish fiscal imbalances much harder after the outbreak of the crisis than before and they showed that the spread on nonbenchmark bonds developed due to the increasing general risk aversion. Their study also confirms that German bonds became safe-haven investments after the crisis - and this is what we used in our yield premia estimations. Antonakakis and Vergos (2013) investigated the spillover effects of sovereign bond yield spread (BYS) between the Eurozone countries in the period 1999-2012 which consist two serious economic shocks namely the global financial crisis and the Eurozone sovereign debt crisis. Their empirical results based on VAR and impulse response estimations and showed that generally bond yield spread enhanced future spreads and the policy changes and news announcements had an impact on them. Moreover the bond yield spread spillovers among the countries in the Eurozone are greatly convuleted and they demonstrated that the Eurozone's boosted vulnerability from the external shocks came largely from the pheriphery member states.

\subsection{Market impacts - from the point of UMP}

Monetary policy influences the decisions of economic agents and the development of macroeconomic variables through the channels of the monetary transmission mechanism. Five channels of monetary transmission can be distinguished: the interest rate, the exchange rate, the asset price, the credit, and the waiting channel, each of which is a unique mechanism through which monetary policy demands are met by commodity market demand. Financial market interest rate decisions and announcements about future decisions are the first to have an impact on financial markets, as market interest rates, asset prices and exchange rates react quickly (Felcser et al. 2015, MNB, 2017). But after the outbreak of the subprime crisis and the advent of unconventional monetary policy, transmission did not always work as usual.

After the 2008, the liquidity of the stock and bond market got more attention, as under the early time of the subprime crisis, credit markets have been frozen and corporate loans have gradually dropped. From this point, main decision-makers started to directly finance the corporate sector through bond markets which was accompanied with a decreasing willingness of the banking 
sector to lend. Moreover, with the implementation of unconventional monetary policy and QE and lending programs began, central banks took the role of the market maker of last resort.

Mentioning the research closest to our topic, but in the US sample, Mallick et al. (2017) examined both the role of stock and bond market volatilities and monetary policy steps in the develop process of the US 10 year term premia. Using VAR models, they proved that a surprising monetary easing (benchmark rate cut, asset purchase programs) reduced market volatility and term premium too. Their other finding is that the volatility of expected equity market is more essential than bond market in this case. They showed that during the the postcrisis period, a bond market shock caused a decline in the term premium which supports the assertion of 'flight to quality'. In a prior study, Gagnon et al. (2017) analysed the domestic and cross-border impacts of the Fed's UMP and their results revealed that the spillover impacts of unconventional measures are heavier due to the larger capital mobility and deeper financial markets. They even presented that these effects are generally greater on foreign bond yields than in exchange rates.

Focusing on the European unconventional monetary policy, Eser and Schwaab (2016) analyzed the yield effects of the Securities Market Programme (SMP) on the sample of 5 sovereign bond markets in the Eurozone, using panel data regression. Their results showed that this QE program enhanced the level of liquidity and reduced default-risk premium. They also proved the "announcement effect" which lead to a decline in bond yield volatility on the days of intervention. But despite the advantageous influences, some European bond yields started to grow again after the primary announcements so then the decision makers expanded the asset purchase programs to other countries. Following the spread of the sovereign debt crisis in Europe, the ECB afterwards introduced other similar programs. There are some recent studies which further scanning the ECB's monetary policy effects within the Eurozone.

Jäger and Grigoriadis (2017) investigated the unconventional monetary steps taken by the ECB with a comparison between crisis and non-crisis periods on a sample of economies in the Eurozone. Using pooled OLS method, their results showed a decrease in sovereign bond yield spreads due to the new policies during 2007-2013. They also proved that the different QE programs had divergent impacts on crisis and non-crisis countries - for example the OMT reduced bond yield spreads for both country groups, while the SMP diminished them in crisis countries and enhanced them is non-crisis countries. Moreover, the ZLB and LTROs are mainly have an impact in non-crisis nations. Using panel models, Fratzscher et al. (2016) investigated the impacts of the ECB's unconventional monetary policy and their results validated that the new instruments had a significant beneficial influence on financial markets in the Eurozone where these had positive spill-overs to international markets (enhanced global asset prices and lowered the global price of risk) by lowering market fragmentation in bond markets and reducing credit risk among banks and sovereigns in the short term. Ciarlone and Colabella (2018) investigated the spillover effects of the Asset Purchase Program (APP) on the financial markets in a sample of Central, Eastern, and Southeastern European (CESEE) countries. Among their findings, we highlight in connection with our topic that they proved that these asset purchases lowered the long-term sovereign yields moderately and they also justified that the outright purchase of financial assets diminished both policy and long-term interest rates to values below the market expected.

About the yield curve effects of UMP, following the ECB's interest rate cut in June 2014, Lemke and Vladu (2017) specified a shadow-rate term structure model (SRTSM) to examine the Eurozone yield curve from 1999 to mid-2015 - when bond yield became negative at 
different maturities. As an innovation of their specification, yields in the model are inhibited by a lower bound, but this bound can change over time. They also confirmed the finding of Kortela (2016) that a time-varying lower bound might be appropriate for the Eurozone to measure the effects of UMP, and this model exceeds the constant lower bound model in the case of the Eurozone. Wu and Xia (2016) analyzed the effects of negative interest rate policy on the yield curve with a new SRTSM for the Eurozone, too. Their main finding is that increasing and decreasing the lower bound had asymmetric impacts on the yield curve.

The transmission of unconventional measures like QE and differs a little from the case of conventional instruments of monetary policy in the case of bond market effects and there are a lot of considerable research about it - with mixed results. Hosono and Isobe (2014) examined the impact of the UMP policies of the Fed, the Bank of England, the ECB and the Bank of Japan on financial markets and their results suggested that these policies reduced long-term government bond yields and exchange rates in most cases and exhibited that stock markets in the Eurozone responded negatively to the shocks of the ECB's unconventional monetary regime. Kenourgios et al. (2019) discovered momentous differences about the correlation between bonds or stock market indices and currency forwards, across the period of the QE programs and their outcomes showed that these instruments affected the correlations between financials assets through the portfolio rebalancing-channel.

However, there is a gap in the literature about the ability of open and small economies around the Eurozone: their yield premiums were less studied compared to the Eurozone member states, which can nuance the overall picture new information in the topic of QE-evaluation.

\subsection{Measuring the recent shocks - subprime crisis, sovereign debt crisis, COVID-19}

An economic or financial shock is an external effect on the economy that displaces macroeconomic and financial variables from their equilibrium trajectories. In this paper, we analyse the most significant shocks of the decade - the subprime crisis, the sovereign debt crisis and the pandemic - in our models.

The indirect impact of monetary policy can generate additional impacts on capital markets in the event of economics shocks. As we mentioned earlier, a liquid and well-developed capital markets can be the key parts to support the efficiency of the monetary easing steps. QE programs have affected these markets, and the role changes of the central bank are also worth mentioning. Emphasizing the importance of the change in the regime of monetary policy, which followed the crisis, our goal was to capture the changes in the central bank balance sheet.

Since 2008, central banks have implemented unconventional monetary regime and pursued the zero interest rate policy, which were used to alleviate the liquidity crisis, after that there was no possibility of further easing by conventional instruments (Joyce et al. 2012). By forward guidance monetary decision makers tried to bring the credibility of the central bank and the expectations of market participants closer to the goals and expectations of the central bank. Originally, the size of the central bank balance sheet $(T A)$ in time $t$, can be written as the sum of foreign exchange reserve $(F X)$, domestic lending $(L)$, domestic securities $(S)$ and other assets $(\kappa)$ - following Ito (2014) (1).

$$
T A=F X+S+L+\kappa, \text { where } \frac{T A_{t}}{T A_{t-1}} \cong \frac{F X_{t}}{F X_{t-1}} \cong \frac{S_{t}}{S_{t-1}} \cong \frac{L_{t}}{L_{t-1}}
$$

Instruments which modified the structure of the balance sheet, was aimed at reducing long-term interest rates but indirectly the caused a restructure in the asset side which did not always entail 
a change in the size of the balance sheet - named as (2) qualitative easing (Borio and Disyatat 2010).

$$
\frac{T A_{t}}{T A_{t-1}} \cong 0 \text { while } \frac{F X_{t}}{F X_{t-1}} ¥ \frac{S_{t}}{S_{t-1}} ¥ \frac{L_{t}}{L_{t-1}}
$$

Quantitative easing (QE) means large-scale asset purchase programs by central banks, complemented by their various credit market interventions, liquidity providing lending - in the sample of EU countries Heryán and Tzeremes (2017) proved that these expanded lending programs had an impact on the bigger and more liquid banks in the Eurozone - programs, as interpreted in our study as the structural changes among the main asset components (3) and whose combined purpose was the reduction of long-term yields (Wang et al. 2015).

$$
\frac{L_{t}+S_{t}}{F X_{t}}>\frac{L_{t-1}+S_{t-1}}{F X_{t-1}}
$$

It was widely assumed that QE reduces the long-term interest rates, improve the credit worthiness, and enhance the reserve accounts of central banks. In many cases, these programs have inflated the previously foreign currency reserve-oriented balance sheet through the purchase of securities, along with changes in the asset side structure (Bernanke 2012). The central bank's QE in a wide scope meant not only buying government securities, but also buying other securities as it also involved the previously mentioned credit loosening processes, which had broader spill-over effects unlike other monetary instruments. This was true for Europe as a whole, despite the relatively late introduction of quantitative easing. Central banks has introduced a wide range of these unconventional measures as we collected and showed in Table 1. Overall, by using these securities and asset purchases central banks targeted to make their monetary policies more accommodative at zero lower bound (ZLB) and to mark and correct the malfunctions of the monetary transmission mechanism (Eser and Schwaab 2016).

\begin{tabular}{|c|c|c|c|c|c|c|}
\hline instrumentcentral bank & $M N B$ & $N B P$ & $C N B$ & $S N B$ & $D N$ & $S R$ \\
\hline asset purchase programs & $\bullet$ & & & & & $\bullet$ \\
\hline forward guidance & $\bullet$ & $\bullet$ & $\bullet$ & $\bullet$ & $\bullet$ & $\bullet$ \\
\hline negative interests & $\bullet$ & & & $\bullet$ & $\bullet$ & $\bullet$ \\
\hline quantity limits on refinancing & $\bullet$ & $\bullet$ & & $\bullet$ & $\bullet$ & $\bullet$ \\
\hline FX swap & $\bullet$ & $\bullet$ & $\bullet$ & $\bullet$ & $\bullet$ & $\bullet$ \\
\hline interest swap & $\bullet$ & & & & & \\
\hline targeted lending & $\bullet$ & & & & & \\
\hline FX ceiling & & & $\bullet$ & $\bullet$ & & \\
\hline asymmetric interest channel & $\bullet$ & & $\bullet$ & & & \\
\hline FX flooring or pegging & $x$ & $x$ & $\checkmark$ & $\checkmark$ & $\checkmark$ & $x$ \\
\hline
\end{tabular}

Table 1: Unconventional monetary instruments (2007-2020)

Source: Authorial edition

On the basis of all this mentioned in this subchapter, we used in our analyses the ratio of the structural changes among the main asset components $\left(\frac{L_{t}+S_{t}}{F X_{t}}\right)$ and the growth of the central bank balance sheet $\left(\frac{T A_{t}}{T A_{t-1}}\right)$ to capture the effects of unconventional monetary policy and QE.

To capture less quantifiable economic shocks, we used dummy variable in our empirical models. Crisis-related dummy variable ${ }^{1}$ will capture the recession in the Euro area. The coronavirus epidemic appeared on the European continent from January 2020, according to

\footnotetext{
${ }^{1}$ Defined by CEPR: global financial crisis: 2008q1-2009q2, Euro zone recession: 2011q3-2012q4
} 
official data ${ }^{2}$, so its effects were captured by a dummy variable calibrated for the first and second quarters of 2020 - but since the use of recession dummy in combination with a variable brought bias into the analysis, we treated it within it, not as a separate dummy variable.

\subsection{Theoretical model}

As Cohen et al. (2018) defined, the yield on long-term bonds consists of two pieces; the returns expected from shorter-term instruments in the same interval and the maturity or another additional element. This maturity or term premia is generally considered to be the supplementary return that investors get as a risk compensation due to the long-term bond. Although it can also be affected by imbalances between supply and demand for a given asset or a number of other determinants. The expected interest rates and term premiums are generally derived using models based on a small number of risk factors, assuming that consistency between yield at different maturities is managed in the lack of arbitrage options.

Since bond markets can be represented well by their yield premiums as the divergence-theory suggests, yield premium will be the dependent variable in our model (4), while general funding environment is represented by the steepness of the yield curve in the Eurozone (the difference between the 10 and the 1 year government bond yields) and the 3 month EURUSD base swap rate $\left(S W A P_{E U R U S D 3 M, t}\right)$ which represents USD funding scarcity following Alvarez et al. (2017). The changes of investors' risk aversion or appetite is captured trough the portfolio investment flows $\left(P F_{Z S C O R E}\right)$ since all sample countries are relying on foreign funding on their sovereign bond markets. The mostly unconventional monetary policy was captured trough two variables: the growth of the central bank balance sheet compared to its initial value in 2007 (total assets: $\left.T A_{B A S E}\right)$ and the structure of the asset side as the loans and securities to foreign exchange rate ratio $(L S F X)$. Meanwhile the macroeconomic environment was represented by the deviation from targeted inflation $\left(I N F L_{G A P}\right)$ and the output gap $\left(O U T P U T_{G A P}\right)$. Recessions were involved trough a dummy variable (DUMMY $Y_{E Z_{R E C}}$ ), containing the COVID-19 period as well.

$$
\begin{aligned}
& \text { INTEREST }_{\text {PREMIUM }, t}=\text { const. }+\alpha_{1} Y C_{\text {STEEPNESS }, t}+\alpha_{2} \text { PF }_{\text {ZSCORE }, t}+\alpha_{3} \text { SWAP }_{\text {EURUSD } 3 M, t}+ \\
& \alpha_{4} T A_{B A S E, t}+\alpha_{5} L S F X_{t}+\alpha_{6} I N F L_{G A P, t}+\alpha_{7} O U T P U T_{G A P, t}+\alpha_{8} D U M M Y_{E Z_{R E C}, t}+ \\
& \beta_{1} \Delta Y C_{\text {STEEPNESS }, t-1: t-k}+\beta_{2} \Delta P F_{\text {ZSCORE,t-1:t-l }}+\beta_{3} \Delta S W A P_{\text {EURUSD } 3 M, t-1: t-f}+ \\
& \beta_{4} \Delta T A_{B A S E, t-1: t-g}+\beta_{5} \Delta L S F X_{t-1: t-h}+\beta_{6} \Delta I N F L_{G A P, t-1: t-h}+\beta_{7} \Delta O U T P U T_{G A P, t-1: t-j}+ \\
& \beta_{8} \Delta D U M M Y_{E Z_{R E C}, t-1: t-n}+\varepsilon_{t}
\end{aligned}
$$

Intuitively we can anticipate the following results from the model, but due to the ARDL method, it is necessary to distinguish between the long run equation which focuses on the size of the variables in time $t$ and the short run equation where the change of each variable has its own lag number, calibrated by the Akaike info criterion (AIC). Therefore, on the long run, a big enough difference between the 10 year and the 1 year in the Eurozone as well as its growth can be interpreted as a sign of increasing long-term funding costs, which spills over to the rest of the sample, creating a higher interest premiums $\left(\alpha_{1}>0, \beta_{1}>0\right)$. Foreign portfolio investors (especially carry traders) may prefer countries with high premium, meaning that we can find high activity in each quarters $\left(\alpha_{2}>0\right)$, but the outflow of this investment can increase the premium due to increasing funding scarcity $\left(\beta_{2}<0\right)$. A positive 3 month EURUSD base swap can be a sign of available funding in USD $\left(\alpha_{3}<0\right)$ which is a sign of calm market conditions, as well as its increase $\left(\beta_{3}<0\right)$. A large central bank balance sheet can be the indicator of an accommodative monetary policy where government bond accumulation has a direct impact on

\footnotetext{
${ }^{2}$ https://ec.europa.eu/info/live-work-travel-eu/health/coronavirus-response/timeline-eu-action_en
} 
the low levels of the premium $\left(\alpha_{4}<0, \beta_{4}<0\right)$. Meanwhile the security and lending dominated balance sheet is a sign of active involvement of lending- and market making of last resort functions, which can calm the markets by a decreasing yield premium or it can make them suspicious depending on the credibility of the central bank $\left(\alpha_{5} \neq 0, \beta_{5} \neq 0\right)$. An increasing or already high inflation is a true indicator for a higher interest premium as well as a huge positive output gap $\left(\alpha_{6}>0, \alpha_{7}>0, \beta_{6}>0, \beta_{7}>0\right)$.

\section{Data and methods}

This section first presents the sources and the developments in the analysed dataset. Then it summarises the methodological backgrounds of the applied ARDL panel regressions. The aim of this paper is to investigate the background of the government 10-year bond yield premia changes in relatively small and open economies around the Eurozone.

\subsection{Data}

Data was collected mainly from central bank databases, Eurostat and stooq.com, covering the period from 2007 Q1 to 2020 Q2. All data was denominated in national currencies.

The standard deviations of interest premiums were calculated against German 10-year government bond yields, because the 10-year maturity is less affected by liquidity turbulences or monetary policy decisions. Because of data availability and flexibility the output gap was calculated from the industrial production index against its HP filtered values. The deviation from inflation target and the balance of portfolio investments are important macro-variables in the case of small open economies, which changes can have a significant impact on financial markets for example through the "flight-to-safety" phenomenon.

Table 2: Variables and their sources

\begin{tabular}{ll}
\hline Variable (2007Q1-2020Q2) & Source \\
\hline 10 -year sovereign yield (10Y) & stooq.com, ECB \\
10-year sovereign yield (10Y) premia & stooq.com, ECB \\
Interest premia & stooq.com, ECB \\
Steepness of the Yield curve & Eurostat \\
Swap (3M EURUSD base SWAP) & Refinitiv Eikon \\
Portfolio investments & Eurostat, central bank data \\
Output gap (industrial production index, HP filter) & Eurostat, OECD \\
Deviation from inflation target & Eurostat \\
CBBS: Balance Sheet size & central banks (Balance sheet data) \\
LSFX = (L+S)/FX reserve ratio & central banks (Balance sheet data) \\
Recession dummy & CEPR-EABCN \\
\hline
\end{tabular}

Source: Authorial edition

Unconventional monetary policy was captured by balance sheet variables into our models. Central bank balance sheets presented a continuous but country-specific growth in the sample which value can be affected by lending expansion, security accumulation programs and foreign exchange reserve changes due to UMP interventions. The Swiss and Czech national banks fought against excessive appreciation. However, structural changes in the balance sheet brought about the UMP are stated by the LSFX ratio, because securities and lending had a mixed importance in the sample. CNB, DN and SR showed an expansionist group, while MNB, PNB, SNB presented a more conservative and foreign exchange reserve oriented subsample.

One dummy variable was introduced in our calculations to making measurable the effects generated by the period of recession due to the subprime crisis, the sovereign debt crisis and to represent the effects of COVID-19 epidemic in our sample. 
Table 3: Descriptive statistics of variables

\begin{tabular}{lllllllll} 
& $\begin{array}{l}\text { INTEREST } \\
\text { PREMIUM }\end{array}$ & $\begin{array}{l}\text { YC_SLOP } \\
\text { ENESS }\end{array}$ & $\begin{array}{l}\text { PF_ } \\
\text { ZSCORE }\end{array}$ & SWAP & TA_BASE & LSFX & $\begin{array}{l}\text { INFL_ } \\
\text { GAP }\end{array}$ & $\begin{array}{l}\text { OUTPUT_ } \\
\text { GAP }\end{array}$ \\
\hline Mean & 1,1702 & 1,5823 & 0,0241 & $-0,3719$ & 2,4971 & 0,2417 & $-0,5547$ & 0,0720 \\
\hline Median & 0,3950 & 1,5633 & 0,0801 & $-0,3000$ & 2,0747 & 0,0586 & $-0,7000$ & 0,0824 \\
\hline Maximum & 7,2800 & 3,0300 & 2,9003 & 0,3800 & 7,8723 & 2,2155 & 5,6000 & 4,5984 \\
\hline Minimum & $-1,6480$ & 0,1733 & $-4,3820$ & $-3,0500$ & 0,8461 & 0,0000 & $-4,1000$ & $-4,8798$ \\
\hline Std. Dev. & 1,7445 & 0,8314 & 0,9751 & 0,4472 & 1,5943 & 0,3940 & 1,6996 & 1,6148 \\
\hline Skewness & 1,0077 & $-0,1235$ & $-0,2973$ & $-4,1232$ & 1,6000 & 2,4504 & 0,6819 & $-0,0309$ \\
\hline Kurtosis & 3,7202 & 1,9902 & 4,1308 & 24,9876 & 5,2888 & 9,4520 & 3,7143 & 2,9790 \\
\hline Jarque-Bera & 60,6873 & 14,3195 & 21,6282 & 7306,7860 & 205,0934 & 869,7998 & 31,4019 & 0,0563 \\
\hline Probability & 0,0000 & 0,0008 & 0,0000 & 0,0000 & 0,0000 & 0,0000 & 0,0000 & 0,9722 \\
\hline Observations & 318 & 318 & 318 & 318 & 318 & 318 & 318 & 318 \\
\hline Source: Auts
\end{tabular}

Source: Authorial edition, using Eviews

All sample variables presented non-normal distribution (Table 3.), except the output gap, while the USDEUR 3M base swap rate had enormous excess kurtosis due to the large swings on the international USD funding market.

\subsection{Method}

The Autoregressive Distributed Lag (ARDL) cointegration technique was implemented by Pesaran and Shin (1999) and further extended by Pesaran et al. (2001). This modelling approach has a lot of econometric advantages in comparison to the other methods of cointegration - like the Johansen cointegration techniques which require larger samples for the results to be valid. ARDL can be applied irrespective of the degree of integration whether I(1) or I(0) and this approach provides robust outcomes in small sample sizes, and estimates of the long-run coefficients are well consistent in small sample sizes too (Pesaran and Shin 1999). The input variables appear as a simple equation, endogeneity is not a problem since the ARDL model is free of correlation between error terms (i.e., all variables are assumed to be endogenous), and the reference model can also be examined. Along a long-term relationship, ARDL can distinguish between dependent and explanatory variables (Nkoro and Uko 2016).

Moreover, a dynamic error correction Term (ECT) can be derived from ARDL that includes the short-run with the long-run estimates without losing long run information. A further advantage using ARDL is that determining the order of the distributed lag function. Pesaran and Smith (1998) showed that the usage of Schwarz-Bayesian criterion (SBC) is more favorable to other model specification criteria because it usually has more close specifications (Dizaji 2012). Due to the mentioned advantages, we use ARDL approach for determining cointegrating relationships in our sample of small open economies.

The ARDL method has two steps; firstly, the existence of a long-run relationship among the variables in the model is determined with cointegration following Pesaran et al. (2001), then to estimate the long-run coefficients of the ARDL model and their asymptotic standard errors. This is followed by the evaluation of the short-run parameters of the variables with the error correction representation of the ARDL model. The unrestricted error correction model is directly derived from the ARDL model. Since the ARDL model is a vector autoregressive (VAR) model, the unrestricted error correction model is a re-parameterisation of this VAR model (Kwesi and Kiss 2017; Lewis and MacDonald 2002; Pesaran et al. 2001).

\section{Results}

Since the ARDL model accepts mixed $\mathrm{I}(0)$ and $\mathrm{I}(1)$ variables, unit root test is necessary only to avoid I(2) cases. For this reason, Table 4. confirms that all variables presented weak stationarity after differentiation. 
Table 4: Levin, Lin \& Chu (2002) $t^{*}$ unit root test (assumes common unit root process)

\begin{tabular}{|c|c|c|c|c|}
\hline & Statistic & Prob.** & sections & Obs \\
\hline d_INTEREST_PREMIUM & -12.1332 & 0.0000 & 6 & 306 \\
\hline d_YC_STEEPNESS & -9.2832 & 0.0000 & 6 & 306 \\
\hline d_PF_ZSCORE & -16.5542 & 0.0000 & 6 & 300 \\
\hline d_SWAP & -19.7739 & 0.0000 & 6 & 306 \\
\hline d_TA_BASE & -7.1985 & 0.0000 & 6 & 306 \\
\hline d_LSFX & -3.3182 & 0.0005 & 7 & 357 \\
\hline d_INFL_GAP & -3.3291 & 0.0004 & 7 & 357 \\
\hline d_OUTPUT_GAP & -15.8790 & 0.0000 & 6 & 306 \\
\hline
\end{tabular}

Source: Authors' calculation, Eviews

The ARDL-model has been calibrated between 0 and 4 lags for the short-term equations, where the AIC proved to be lowest in the case of using 4 lags for all the variables (Table 5.). The ARDL model provides simultaneous analysis both on level and differentials. The level-part of the equation informs us about the size-impact of the explanatory variables, while the differential-part shows the influence of the changes in these variables. Both the high levels and the increasing nature of yield premiums are the indicators of divergence in funding terms, which informs us about the region-specific concerns of the investors.

Our results are showing that only the level of base swap (SwAP) rates, central bank balance sheets (TA_BASE) and the macro-conditions (INFL_GAP, OUTPUT_GAP) had significant contribution. A high and positive 3M EURUSD base swap (swaP) rate indicates the lack of scarcity in international USD funding, however its negative values can be paired with high interest premium which fits to the expectations that a global funding discrepancies have immediate regional implications. An accommodative monetary policy (which can be captured via the size and composition of the balance sheet) should have a calming impact on the domestic bond markets. However, for open and small economies, the higher market share of foreign funding can hinder these intentions, what was visible in the case of the central bank balance sheet (TA_BASE) size. Both the sheer size and the increasing nature contributed to the high levels and to the increase of the yield premium - pointing on the dangers of economic activism for small and open economies. However, the ratio of lending and securities (LSFX) had no significant impact for either short-term and long-term run equations, thus, the structural changes in the central bank's assets, and thus the shifts in its applied instruments from the increase in foreign exchange reserves, did not influence the bond yield premium in the examined sample. Excessive inflation and high output levels are excellent indicators for an overheated economy, which elevated risk levels should be rewarded with higher yield premiums. This intuition was supported by the macroeconomic variables (INFL_GAP, OUTPUT_GAP), since both of them had strong positive influence on the size of the premium. The central bank in the sample have to operate in an environment which is dominated by the actions of the European Central Bank, therefore they have a limited degree of freedom (and autonomy as well). The significant influence of the Eurozone's term-premium (YC_SLOPENESS) is a clear indicator for this effect: as the term-premiums of the long-term yields are increasing the Eurozone, regional yieldpremiums are increasing as well on medium-run.

It is interesting to see that portfolio investment flows (PF_ZSCORE) had no significant individual impact which means that the bond markets of these small open economies were not dependent on portfolio capital flows during the period under review. However, its exclusion would have raised an omitted variable bias for this model. 
Table 5: Results of the ARDL model, Dependent Variable: D(INTEREST_PREMIUM)

\begin{tabular}{|c|c|c|c|c|}
\hline Variable & Coefficient & Std. Error & t-Statistic & Prob.* \\
\hline & \multicolumn{4}{|c|}{ Long Run Equation } \\
\hline YC_SLOPENESS & -3.5011 & 2.4144 & -1.4501 & 0.1506 \\
\hline PF_ZSCORE & 0.4607 & 0.8151 & 0.5652 & 0.5733 \\
\hline SWAP & -13.8041 & 7.4230 & -1.8596 & 0.0663 \\
\hline TA_BASE & 3.8665 & 2.1587 & 1.7911 & 0.0767 \\
\hline LSFX & -1.9267 & 1.5045 & -1.2806 & 0.2037 \\
\hline INFL_GAP & 3.3843 & 1.7429 & 1.9417 & 0.0554 \\
\hline OUTPUT_GAP & 3.4681 & 1.7963 & 1.9307 & 0.0567 \\
\hline \multirow[t]{2}{*}{ DUMMY_EZ_REC } & -3.0890 & 1.8335 & -1.6847 & 0.0956 \\
\hline & \multicolumn{4}{|c|}{ Short Run Equation } \\
\hline COINTEQ01 & -0.0143 & 0.0236 & -0.6039 & 0.5475 \\
\hline D(INTEREST_PREMIUM(-1)) & -0.2909 & 0.1056 & -2.7556 & 0.0071 \\
\hline D(INTEREST_PREMIUM(-2)) & -0.4789 & 0.1215 & -3.9411 & 0.0002 \\
\hline D(INTEREST_PREMIUM(-3)) & -0.1180 & 0.1022 & -1.1551 & 0.2512 \\
\hline D(YC_SLOPENESS) & -0.1315 & 0.0599 & -2.1955 & 0.0308 \\
\hline D(YC_SLOPENESS(-1)) & 0.0201 & 0.1146 & 0.1752 & 0.8613 \\
\hline D(YC_SLOPENESS(-2)) & 0.1261 & 0.1466 & 0.8597 & 0.3923 \\
\hline D(YC_SLOPENESS(-3)) & 0.2547 & 0.1337 & 1.9046 & 0.0601 \\
\hline D(PF_ZSCORE) & -0.0137 & 0.0261 & -0.5255 & 0.6006 \\
\hline D(PF_ZSCORE(-1)) & -0.0373 & 0.0366 & -1.0200 & 0.3105 \\
\hline D(PF_ZSCORE(-2)) & -0.0225 & 0.0233 & -0.9655 & 0.3369 \\
\hline D(PF_ZSCORE(-3)) & 0.0125 & 0.0231 & 0.5412 & 0.5898 \\
\hline D(SWAP) & 0.2581 & 0.3104 & 0.8314 & 0.4080 \\
\hline D(SWAP(-1)) & 0.0962 & 0.2682 & 0.3586 & 0.7207 \\
\hline D(SWAP(-2)) & -0.1259 & 0.1963 & -0.6412 & 0.5230 \\
\hline D(SWAP(-3)) & -0.1231 & 0.1497 & -0.8223 & 0.4131 \\
\hline D(TA_BASE) & 0.2492 & 0.2335 & 1.0674 & 0.2887 \\
\hline D(TA_BASE(-1)) & 0.1839 & 0.2432 & 0.7560 & 0.4517 \\
\hline D(TA_BASE(-2)) & 0.3481 & 0.3849 & 0.9044 & 0.3682 \\
\hline D(TA_BASE(-3)) & 0.5656 & 0.2965 & 1.9073 & 0.0597 \\
\hline D(LSFX) & -0.8572 & 3.0568 & -0.2804 & 0.7798 \\
\hline D(LSFX(-1)) & 5.5341 & 3.6996 & 1.4959 & 0.1383 \\
\hline D(LSFX(-2)) & -1.0988 & 4.6655 & -0.2355 & 0.8143 \\
\hline D(LSFX(-3)) & 6.0374 & 4.2355 & 1.4254 & 0.1576 \\
\hline D(INFL_GAP) & 0.0604 & 0.0508 & 1.1903 & 0.2371 \\
\hline D(INFL_GAP(-1)) & 0.0125 & 0.0742 & 0.1679 & 0.8670 \\
\hline D(INFL_GAP(-2)) & -0.0656 & 0.0721 & -0.9105 & 0.3650 \\
\hline D(INFL_GAP(-3)) & 0.0220 & 0.0636 & 0.3464 & 0.7299 \\
\hline D(OUTPUT_GAP) & 4.7386 & 3.5374 & 1.3396 & 0.1838 \\
\hline D(OUTPUT_GAP(-1)) & -11.8404 & 9.5357 & -1.2417 & 0.2176 \\
\hline D(OUTPUT_GAP(-2)) & 10.0394 & 9.3756 & 1.0708 & 0.2872 \\
\hline D(OUTPUT_GAP(-3)) & -2.6493 & 3.3959 & -0.7801 & 0.4374 \\
\hline D(DUMMY_EZ_REC) & 0.1824 & 0.0967 & 1.8858 & 0.0626 \\
\hline D(DUMMY_EZ_REC(-1)) & 0.0826 & 0.0761 & 1.0866 & 0.2802 \\
\hline D(DUMMY_EZ_REC(-2)) & 0.1220 & 0.0674 & 1.8103 & 0.0737 \\
\hline D(DUMMY_EZ_REC(-3)) & -0.1478 & 0.1618 & -0.9138 & 0.3633 \\
\hline $\mathbf{C}$ & -0.0460 & 0.0858 & -0.5365 & 0.5930 \\
\hline Root MSE & 0.0945 & \multicolumn{2}{|c|}{ Mean dependent var } & 0.0136 \\
\hline S.D. dependent var & 0.3362 & \multicolumn{2}{|c|}{ S.E. of regression } & 0.1797 \\
\hline Akaike info criterion & -0.7243 & \multicolumn{2}{|c|}{ Sum squared resid } & 2.8425 \\
\hline Schwarz criterion & 1.9967 & \multicolumn{2}{|c|}{ Log likelihood } & 345.1597 \\
\hline Hannan-Quinn criter. & 0.3625 & & & \\
\hline
\end{tabular}

Notes: Model selection method: Akaike info criterion (AIC) 0-4 lags, Selected Model: ARDL(4, 4, 4, 4, 4, 4, 4, 4,4) Significant values are indicated in bold. Source: Authors' calculation, Eviews

\section{Conclusion}

The connection between bond markets and monetary policy and economic shocks has not get enough attention yet, even though the role of them become increasingly important since the big financial crisis. Moreover, we found that there is a gap in the literature about the ability of open and small economies around the Eurozone: their yield premiums were less studied compared to the Eurozone member states, which can nuance the overall picture new information in the topic of QE-evaluation. For this reason, the aim of our research was to examine the background of the 10-year bond yield premia changes in relatively small and open economies outside the 
Eurozone. Our goal was to explore the specific aspects of the relationship between shock events (the economic crisis of 2008, the subsequent European sovereign debt crisis and the current corona virus epidemic) and credit market mechanisms, and within this, the situation of small, open economies - such as the Czech, Danish, Polish, Hungarian, Swiss and Swedish central banks. We answered our research question through ARDL panel regressions, by which we tested the fulfilment of our pre-compiled empirical model focusing on mainly the side-effects of unconventional monetary policy.

Our results showed that the ratio of lending and securities had no significant impact on yield premia, but the inflated central bank balance sheets paired with high yield premium, what was supported by their increase - leading to the key policy implication of this paper: meaning that $\mathrm{QE}$ is not for small and open economies. The analysed central banks have a limited degree of freedom because they operate in an environment which is dominated by the actions of the ECB, which was supported our results about the yield curve slopeness variable; as the term-premiums of the long-term yields are increasing the Eurozone, regional yield-premiums are increasing as well on medium-run.

Negative base swap rates could be paired with high interest premium which fits to the general expectations and this ratio even had this highest magnitude among all among all examined variables. Contrary to expectations, no significant effect of portfolio capital flow could be measured on the sample which means that the bond markets of these small open economies were not dependent on portfolio capital flows during the period under review. At the same time, the macroeconomic variables had strong influence on the bond market: high inflation and output gap leads to increased level of yield premium.

As a future research, it may be interesting to examine the effects of these analysed variables (and more additional ones) on bond yield volatility through other econometric methods. In addition, the distribution of the investigated period by economic shocks may be worthwhile and this can show new results that are useful to compare - although for this at least 3-4 more quarterly data needed to make proper measurements about the effects of the latest coronavirus epidemic.

\section{Acknowledgement}

Supported by the ÚNKP-20-3 - New National Excellence Program of the Ministry for Innovation and Technology from the source of the National Research, Development and Innovation Fund.

\section{References}

[1] ADRIAN, T. and H. S. SHIN, 2010. Liquidity and leverage. Journal of financial intermediation, 19(3), pp. 418-437.

[2] AFONSO, A., 2010. Long-term government bond yields and economic forecasts: evidence for the EU. Applied Economics Letters, 17(15), pp. 1437-1441.

[3] ALVAREZ, I., F. CASA VECCHIA, M. DE LUCA, A. DUERING, F. ESER, C. HELMUS and C. HEMOUS, 2017. The Use of the Eurosystem's Monetary Policy Instruments and Operational Framework since 2012. ECB Occasional Paper 188. European Central Bank

[4] ANTONAKAKIS, N. and K. VERGOS, 2013. Sovereign bond yield spillovers in the Euro zone during the financial and debt crisis. Journal of International Financial Markets, Institutions and Money, vol. 26, pp. 258-272. 
[5] BALLI, F., 2009. Spillover effects on government bond yields in euro zone. Does full financial integration exist in European government bond markets?. Journal of Economics and Finance, 33(4), pp. 331.

[6] BERNANKE, B. S., 2012. Monetary Policy since the Onset of the Crisis. Remarks at the Federal Reserve Bank of Kansas City Economic Symposium, Jackson Hole, Wyoming, 2012.09.31.

[7] BORIO, C. and P. DISYATAT, 2010. Unconventional monetary policies: an appraisal. The Manchester School, vol. 78, pp. 53-89.

[8] CIARLONE, A. and A. COLABELLA, 2018. International Spillovers of Non-standard Monetary Policy: Evidence From Central and Eastern Europe. In International Macroeconomics in the Wake of the Global Financial Crisis (pp. 271-298). Springer, Cham.

[9] CLAEYS, P. and B. VAŠÍČEK, 2014. Measuring bilateral spillover and testing contagion on sovereign bond markets in Europe. Journal of Banking \& Finance, vol. 46, pp. 151165 .

[10] DIZAJI, S. F., 2012. Exports, Government Size and Economic Growth (Evidence from Iran as a developing oil-export based economy). ISS Working Paper Series/General Series, 535(535), pp. 1-41.

[11] ESER, F. and B. SCHWAAB, 2016. Evaluating the impact of unconventional monetary policy measures: Empirical evidence from the ECB' s Securities Markets Programme. Journal of Financial Economics, 119(1), pp. 147-167.

[12] FELCSER D., G. D. SOÓS and B. VÁRADI, 2015. A kamatcsökkentési ciklus hatása a Magyar makrogazdaságra és a pénzügyi piacokra. Hitelintézeti Szemle, 14(3), pp. 39-59.

[13] FRATZSCHER, M., M. L. DUCA and R. STRAUB, 2016. ECB unconventional monetary policy: Market impact and international spillovers. IMF Economic Review, 64(1), pp. 3674.

[14] GAGNON, J. E., T. BAYOUMI, J. M. LONDONO, C. SABOROWSKI and H. SAPRIZA, 2017. Direct and spillover effects of unconventional monetary and exchange rate policies. Open Economies Review, 28(2), pp. 191-232.

[15] HE, Z. and A. KRISHNAMURTHY, 2013. Intermediary asset pricing. American Economic Review, 103(2), pp. 732-70.

[16] HERYÁN, T. and P. G. TZEREMES, 2017. The bank lending channel of monetary policy in EU countries during the global financial crisis. Economic modelling, vol. 67, pp. 10-22.

[17] HOSONO, K. and S. ISOBE, 2014. The Financial Market Impact of Unconventional Monetary Policies in the U.S., the U.K., the Eurozone, and Japan 1.

[18] ITO, T., 2014. We are all QE-sians now. Institute for Monetary and Economic Studies, Bank of Japan, Discussion Paper, (2014-E), 5.

[19] JÄGER, J. and T. GRIGORIADIS, 2017. The effectiveness of the ECB's unconventional monetary policy: Comparative evidence from crisis and non-crisis Euro-area countries. Journal of International Money and Finance, vol. 78, pp. 21-43.

[20] JOYCE, M., D. MILES, A. SCOTT and D. VAYANOS, 2012. Quantitative easing and unconventional monetary policy-an introduction. The Economic Journal, 122(564), pp. F271-F288. 
[21] KENOURGIOS, D., E. DRAKONAKI and D. DIMITRIOU, 2019. ECB's unconventional monetary policy and cross-financial-market correlation dynamics. The North American Journal of Economics and Finance, 50, 101045.

[22] KORTELA, T., 2016. A shadow rate model with time-varying lower bound of interest rates. Bank of Finland Research Discussion Paper, (19).

[23] KWESI, A. I. and G. D. KISS, 2017. External debt and capital flight: is here a revolving dood hypothesis in Ghana?. In 13th Annual International Bata Conference for Ph. D. Students and Young Researchers (p. 21).

[24] LEMKE, W. and A. L. VLADU, 2017. Below the zero lower bound: a shadow-rate term structure model for the euro area (No. 1991). ECB Working Paper.

[25] LEVIN, A., C. F. LIN and C. S. J. CHU, 2002. Unit root tests in panel data: asymptotic and finite-sample properties. Journal of econometrics, 108(1), pp. 1-24.

[26] LEWIS, P. E. and G. MACDONALD, 2002. The elasticity of demand for labour in Australia. Economic Record, 78(240), pp. 18-30.

[27] MALLICK, S., M. MOHANTY and F. ZAMPOLLI, 2017. Market volatility, monetary policy and the term premium (No. 606). Bank for International Settlements.

[28] MNB, 2017. Modern jegybanki gyakorlat. Vonnák Balázs (eds.), Budapest: Magyar Nemzeti Bank.

[29] NKORO, E. and A. K. UKO, 2016. Autoregressive Distributed Lag (ARDL) cointegration technique: application and interpretation. Journal of Statistical and Econometric Methods, 5(4), pp. 63-91.

[30] PAGANO, M. and E. L. VON THADDEN, 2004. The European bond markets under EMU. Oxford review of economic policy, 20(4), 531-554.

[31] PESARAN, M. H. and Y. SHIN, 1998. An autoregressive distributed-lag modelling approach to cointegration analysis. Econometric Society Monographs, vol. 31, pp. 371413.

[32] PESARAN, M. H., Y. SHIN and R. J. SMITH, 2001. Bounds testing approaches to the analysis of level relationships. Journal of applied econometrics, 16(3), pp. 289-326.

[33] PESARAN, M. H. and R. P. SMITH, 1998. Structural analysis of cointegrating VARs. Journal of Economic Surveys, 12(5), pp. 471-505.

[34] VERES, I., 2016. Kötvénymatematika, in: Magyar Nemzeti Bank - Oktatási Füzetek, June 2016, Budapest (https://www.mnb.hu/letoltes/mnb-oktatasi-fuzetek-2016-2szamkotvenymatematika.pdf)

[35] VON HAGEN, J., L. SCHUKNECHT and G. WOLSWIJK, 2011. Government bond risk premiums in the EU revisited: The impact of the financial crisis. European Journal of Political Economy, 27(1), pp. 36-43.

[36] WANG, Y. C., C. W. WANG and C. H. HUANG, 2015. The impact of unconventional monetary policy on the tail risks of stock markets between US and Japan. International Review of Financial Analysis, vol. 41, pp. 41-51.

[37] WU, J. C. and F. D. XIA, 2016. Measuring the macroeconomic impact of monetary policy at the zero lower bound. Journal of Money, Credit and Banking, 48(2-3, pp. 253-291. 